\title{
Development of the Public Sector HRM Model in Indonesia's Public Sector
}

\author{
Bambang Irawan ${ }^{1 *}$, Faria Ruhana ${ }^{2}$, Abdul Nadjib ${ }^{3}$, Irwandi ${ }^{4}$, Ananda Rivaldo Sari ${ }^{5}$ \\ ${ }^{1}$ Institut Ilmu Sosial dan Manajemen STIAMI, Indonesia \\ ${ }^{2}$ Institut Pemerintahan Dalam Negeri, Indonesia \\ ${ }^{3}$ FISIP Universitas Sriwijaya Palembang, Indonesia \\ ${ }^{4}$ UIN Sunan Gunung Djati, Bandung, Indonesia \\ ${ }^{5}$ GoAcademica Result and Publishing, Indonesia \\ Corresponding Email: bbgirw7980@gmail.com
}

\begin{abstract}
HRM (Human Resource Management) is crucial to the success of any business, achieving organizational goals. It has a special function as a strategic administrative instrument because it utilizes human resources (HR) based on efficiency, effectiveness, rationality, and objectivity. However, in Indonesia's bureaucratic system, there are still several human resource constraints that become a problem in public services. The aim of this paper is to examine the technical concepts of the HRM model and to create a hypothetical HRM model for the public sector. By using descriptive and secondary data analysis techniques. As a rationale, the public sector HRM model should be combined with those values from the good governance paradigm, as per the findings of this study.
\end{abstract}

Keywords: public sector, HRM model, sound governance

\section{INTRODUCTION}

Human Resource Management (HRM) is an essential place for companies to accomplish their aims. (Andra, 2020). The large role of the bureaucracy in delivering community services in the public market price experienced and efficient support. Human Resources (HR) of the apparatus (Sukriyani, 2021). In the context HRM is one of the pillars of progress and organizational and structure aspects of administrative reform. The effective and efficient utilization of human resources for the bureaucracy is the main function of HRM for the bureaucracy, from planning to HR's termination (Widami, 2020).

As found in various literature management pieces, achieving organizational goals in a managerial manner begins with the planning function. The apparatus's planning involvement has a significant role, especially in their attitudes and behavior (Silvia, 2021). The philosophy Officials participating in planning play a critical role in determining that public sector organisations meet their aims, and the influence of several other technical variables. If, in the planning stage, quality human resources have an important role in achieving the set targets, then the next bureaucratic managerial process in the form of direction, implementation, and evaluation must also be supported by qualified officials (Sukriyani, 2021).

In such a context, HRM is challenged to answer the problem of improving the apparatus's quality. Until now, the bureaucratic apparatus's quality in providing public services in Indonesia is still a very serious problem (Prasodjo, 2020). As users of bureaucratic services, the community often complains about the quality of the officials in carrying out their functions (Luu \& Luong, 2021). Various forms of complaints arise from the service process, the time it takes to resolve affairs, officials' attitudes, and behavior to the quality of service results. This serious, unresolved problem has finally positioned Indonesia as a country that is not conducive to public services (Puspitawaty, 2020).

The role of HRM in the public sector is very critical, and the conditions are different from that of the private sector. Historically, the concepts developed in HRM have originated from private 
sector business activities (Arliliwati \& Yulianti 2020).

For companies, HRM is not just an instrument of employee utilization. HRM in the private sector is also a strength for companies in achieving competitive advantage in the global era (Ingsih \& Suhana, 2020). HRM can function effectively in the private sector, while this is not the case in the public sector (Hamid \& Bijang, 2020). One of the determining factors for the effectiveness of HRM has to do with the organizational culture of the private sector, which is in stark contrast to the public sector (Dahlan \& Fatmawada, 2020). In addition to culture, and while researching public sector organisations, an unfavorable organizational climate and managerial ideals that are insignificant to change become bureaucratic obstacles to achieving organizational effectiveness in researching public sector organizations and the police in Indonesia (Soetjipto, 2021).

HRM must be described in terms of history, organizational climate, and corporate values by academicians and policymakers. Typical of the bureaucracy that is different from companies representing the private sector. With the belief that the culture and organizational climate and managerial values can support the achievement of corporate competitive advantage, this paper is intended to describe the phenomenon and an introduction to the development of the HRM model in the public sector so that it can be seen as a model for establishing a strong bureaucracy capable of providing elevated services. Contribute to the development of Indonesia's competitiveness (Khan, 2021).

\section{METHOD}

The research method used in this research is descriptive analysis with a deductive pattern. The method used in this research is a quantitative study. Data is taken from various scientific writing sources.

\section{RESULT AND DISCUSSION}

\section{Basic Principles of HRM}

The meaning of the system and role can both be used to explain HRM in general. HRM is nothing more than a risk management that is purposefully structured to ensure that all individuals' potential or skills in the organization are effectively and efficiently used. The use of these individuals is meant to accomplish certain goals and objectives. Psychology is one of the scientific disciplines that has a significant impact on organisations' ability to chart individual potential and make it useful in supporting work implementation (Valencia, 2020).

The system is then implemented into several HRM functions, which eventually form a definitive formulation of functional HRM, namely "all activities starting with HR planning to the dismissal or termination of HR" (Rahman \& Amin, 2020). The preparation of job evaluations, followed by HR recruiting, selection, and placement of HR in relevant positions, are one of the other vital activities after the planning function and before the termination of HR.", then successively the functions of payroll, performance appraisal, training and development, career management in classes, fostering employee relationships, as well as designing various quality work-life programs.

However, HRM is not sufficiently understood only in terms of systems and functions. HRM will have a more comprehensive meaning for the organization from a policy perspective (Amelia \& Sijabat, 2020). From a policy perspective, HRM is classically meaningful as a form of organizational policy that is deliberately built to maximize the integration of all elements of organizational integration, build employee commitment, apply the principle for flexibility in the implementation of managerial functions and jobs to prevent rigidity, and achieve quality in both the implementation process and the outcomes of the job performance. From this policy point of view, a thought has finally developed that the full meaning of HRM is not limited in a purely technical sense. More than a technical issue, HRM has also experienced a convergence of more substantial roles (Boudlaie, 2020).

In executing managerial functions, a public sector follows the same rules as the private sector. Since the 1990s, when the organizational climate was defined through intense complexities, executive positions are directed at developing individual behavior by emphasizing five aspects, namely: (1) A focus on the people; (2) participative governance; (3) creative workstyles; (4) strong client orientation; and (5) a main objective mindset (Prasada \& Teriyan, 2020).

Naturally, organizations are held to meet human needs (Septiani \& Siswadhi, 2020). 
Meanwhile, in utilizing human resources, the organization explicitly shows humans' position as the main element in it (Musadadd, 2020). Thus, the organization's human component is passive but is more active in facing several challenges and is ready to develop itself for the continuity of the organization itself. The development of human resource quality based on several studies' results is believed to improve organizational performance (Muriawan, 2020).

HRM has a participatory leadership principle. If we look at the first HRM principle, which positions the human element as an active party, this second principle also places the leader figure as an involved party and not just a situational one. Theoretically, the best leadership is to adapt to all changes in situational forms. However, the best of the best direction is the ability to adapt activities to the leader and the level of intensive involvement create an innovative atmosphere at all levels of the company The third fundamental concept of HRM applies to creative action that goes beyond what a person should accomplish (Robbi, 2020). This third principle refers to the individual's ability to focus on the completed performance and then research it in order to improve it in the future.

Due to the intensifying level of competition, the orientation of the organization tends to get an outward focus Customer satisfaction (for the private sector) and society (for the public sector) are not always a goal, but also a "instrument" for organizations to achieve a lengthy competitive advantage in this context (SCA), or a sustainable competitive advantage. The fourth principle of HRM plays a very important role in the scarcity of resources. Namely, the available resources are increasingly limited. Simultaneously, the community's needs for corporate products and services have become more diverse, resulting in a higher need for resources increases.

Meanwhile, the fifth principle in HRM continues to position the individual central figure as a party that upholds some noble values that can direct him/her to various improvement efforts. Mindset is a crucial term that demonstrates how people's perceptions, attitudes, and actions often contribute to organizational performance. Organizational excellence can be achieved by human capital development as a tool to win the market and achieve results, as per experience from many other countries. The five principles of HRM are important lessons in building a quality organization centered on
HR development. These HRM principles also reiterate that without quality human resources, an organization will certainly not achieve success.

\section{Public Sector HRM Model Construction}

The substance of a sound governance paradigm is policy and administration development innovation. The age of proper governance, which reflects the most recent paradigm of State Administration, calls for a specific combination of HRM elements to support the creation of public service innovation. This mixture includes, among other things, expertise, skills, and attitudes, as well as the development of a system capable of attracting, retaining, developing, and motivating human resources so that the bureaucracy can obtain and employ apparatus with appropriate caliber criteria (Sedarmayanti, 2020). It is from this view that a hypothetical and idealized model of public sector HRM may be developed. As a consequence, in order to build a theoretical model of public sector HRM that embraces an enabling bureaucracy, several aspects that have been discussed in this paper must be considered.

In connection with the formulation of a hypothetical model of HRM in the public sector, there is one important note that needs to be underlined, namely the tendency of the nature or form of the model to accommodate various aspects that must be considered according to the basic idea of the good governance paradigm. The public sector HRM model must be differentiated to be a traditional bureaucratic model or a new management approach. Keeping in mind the category as a hypothetical model, the public sector HRM model is ideal (normative). Because of in-depth study through research and looking at practical experiences, this model can develop according to changing contexts, both in the dimensions of space and time.

\section{CONCLUSION}

In order to develop policy and support administrative tasks, the sound governance model requires innovation in the bureaucracy. Constructing a model composed of different philosophical and functional elements demonstrates the integration of public sector HRM. The public sector HRM model includes the significant meaning and significant role of HRM, as well as actual HRM challenges, basic HRM rules, and comparisons against various expert models. 
Following the the public sector HR management model tends to be based on a new management strategy rather than a traditional bureaucratic mechanism in the good governance paradigm, which relies on innovation in policy development and administrative functions. HRM is now more integrated and contextual in the public sector, it is hoped that there will be an increase in the quality of human capital in order to support the bureaucracy in achieving innovation in policy making and administrative functions.

\section{REFERENCES}

[1] Amelia, D., \& Sijabat, R. (2020). The Impact of Human Resources Management Practices on Job Performance: The Case of Nurses at Siloam Lippo Village Hospital. Jurnal Keperawatan Soedirman, 15(3).

[2] Andra, N. (2020). Pengaruh Sistem Pengembangan Karir Terhadap Kinerja Pelayanan Publik Pegawai Negeri Sipil Melalui Kepuasan Sebagai Variable Intervening Di Badan Kepegawaian Dan Pengembangan Sumber Daya Manusia (BKPSDM) Kota Sungai Penuh. Jurnal Administrasi Nusantara Maha, 2(10), 33-52.

[3] Arliliwati, Z. R., \& Yuliani, F. (2020). Evaluasi Manajemen Pelayanan Publik. JIANA (Jurnal Ilmu Administrasi Negara), 15(3), 323-327.

[4] Boudlaie, H., Mahdiraji, H. A., Shamsi, S., Jafari-Sadeghi, V., \& Garcia, P. A. (2020). Designing a human resource scorecard: An empirical stakeholder-based study with a company culture perspective. Journal of Entrepreneurship, Management and Innovation, 16(4), 113-147.Dahlan, D., \& Fatmawada, F. (2020).

[5] The Fusion of Competence and Integrity Problems in Transformation of Public Human Resources Management Model. Jurnal Ilmiah Ilmu Administrasi Publik, 9(2), 185-190.

[6] Hamid, H., Haming, M., Semmaila, B., \& Bijang, J. (2020). A mediation effect of new public management on the relationship between intelligence, leadership, HR quality and performance of local government employees in Indonesia. Management Science Letters, 10(7), 1401-1408.

[7] Ingsih, K., Prayitno, A., Waluyo, D. E., \& Suhana, S. (2020). Mediating roles of job satisfaction toward the organizational commitment of employees in the public sector. The Journal of Asian Finance, Economics, and Business, 7(10), 999-1006.

[8] Khan, A. (2021). Optimalisasi Pelayanan Publik Bagi Pemimpin di Era Digitalisasi di Provinsi Riau. Jurnal Niara, 14(2), 9-14.

[9] Losa, K. A. (2020). Analisis Faktor Faktor Kualitas Pelayanan Publik Pada Bidang Kesejahteraan Masyarakat (KESRA) Di Kantor Kelurahan Sempaja Timur. Administrasi Publik, 1(2), 833-850.

[10] Luu, T. T., Vu, T. N., Rowley, C., \& Luong, T. P. N. (2021). Nurturing mutual gains in the public sector: the roles of socially responsible human resource practices, employee use of normative public values, and job crafting. Public Management Review, 1(2), 1-31.

[11] Muriawan, A., Subarkah, S., \& Sulistyowati, S (2020). Optimalisasi Pelayanan Publik (Kajian Layanan Administrasi Kependudukan Di Tingkat Kecamatan Kota Kudus). Jurnal Suara Keadilan, 21(1), 1-16.

[12] Musaddad, A. A., Niswah, M., Prasetyo, K., \& Hardjati, S. (2020). Implementasi Manajemen Kearsipan Di Sektor Publik. Jurnal Governansi, 6(2), 133-143.

[13] Prasada, D., Sunarsi, D., \& Teriyan, A. (2020). Pengaruh Etos Kerja Dan Kompensasi Terhadap Komitmen Organisasi Pada DHL Logistic Di Jakarta. JENIUS (Jurnal Ilmiah Manajemen Sumber Daya Manusia), 4(1), 51-60.

[14] Prasodjo, T. (2020). Knowledge Management: Sustainable Human Resource Development in Public Sector Organizations. Jurnal Ad'ministrare, 6(2), 159-166.

[15] Puspitawaty, S. (2020). Pengaruh Motivasi Dan Kompetensi Terhadap Kinerja Front Office Yang Berdampak Pada Kualitas Pelayanan Publik. Jurnal Ekonomi Manajemen Sistem Informasi, 2(2), 148-159.

[16] Rahman, M. H., Mutsuddi, P., Roy, S. K., AlAmin, M., \& Jannat, F. (2020). Performance Efficiency Evaluation of Information and Communication Technology (ICT) Application in Human Resource Management during COVID-19 Pandemic: A Study on Banking Industry of Bangladesh. South Asian Journal of Social Studies and Economics, 46-56.

[17] Robbi, R. R., Parawu, H. E., \& Tahir, N. (2020). Analisis Kinerja Pegawai Untuk Meningkatkan Kualitas Pelayanan Publik Di Kantor BPJS Kesehatan Cabang Makassar. Dinamika Governance: Jurnal Ilmu Administrasi Negara, 10(2). 
[18] Sedarmayanti, S. (2020). Manajemen Sumber Daya Manusia Dalam Meningkatkan Kinerja Daerah. Jurnal Wacana Kinerja: Kajian PraktisAkademis Kinerja dan Administrasi Pelayanan Publik, 5(4), 21-30.

[19] Septiani, E., \& Siswadhi, F. (2020). Pelayanan Publik Dalam Perpektif Administrasi Publik Di Indonesia. Syntax Literate; Jurnal Ilmiah Indonesia, 5(5), 55-67.

[20] Silvia, S. (2021). Studi Tentang Kinerja Pelayanan Publik Pada Kantor Kelurahan Sungai Kapih Kota Samarinda. Administrasi Publik, 1(2), 973-992.

[21] Soetjipto, N., Sulastri, S., Prastyorini, J., Soedarmanto, S., \& Riswanto, A. (2021). Implementation of enterprise human resources management standards to achieve supply chain excellence in fertilizer companies in Indonesia. Uncertain Supply Chain Management, 9(1), 107-114.

[22] Sukriyani, S. (2021). The Effects of Motivation, Compensation, and Work Environment on the Performance of Local Public Officer. Budapest International Research and Critics Institute (BIRCI-Journal): Humanities and Social Sciences, 4(1), 903-917.

[23] Valencia, I. A. (2020). Exploring Prime-Human Resource Management and Organizational Commitment: A Perspective. PalArch's Journal of Archaeology of Egypt/Egyptology, 17(2), 501517. 